Article

\title{
Design of Highly Active Electrodes for Hydrogen Evolution Reaction Based on Mo-Rich Alloys Electrodeposited from Ammonium Acetate Bath
}

\author{
Edita Vernickaite ${ }^{1}$, Oksana Bersirova ${ }^{2}$, Henrikas Cesiulis ${ }^{1}$ (i) and Natalia Tsyntsaru ${ }^{1,3, *(1)}$ \\ 1 Department of Physical Chemistry, Vilnius University, Naugarduko str. 24, LT-03225 Vilnius, Lithuania; \\ edita.vernickaite@chf.vu.lt (E.V.); henrikas.cesiulis@chf.vu.lt (H.C.) \\ 2 V.I. Vernadsky Institute of General and Inorganic Chemistry, 32-34 Acad. Palladina ave., 03680 Kiev, Ukraine; \\ bersirova@nas.gov.ua \\ 3 Institute of Applied Physics, Academiei str. 5, MD-2028 Chisinau, Moldova \\ * Correspondence: ashra_nt@yahoo.com; Tel.: +370-672-28632
}

Received: 15 January 2019; Accepted: 29 January 2019; Published: 30 January 2019

check for updates

\begin{abstract}
The given research was driven by prospects to design Mo-rich coatings with iron group metals electrodeposited from a highly saturated ammonium acetate bath. The obtained coatings could be employed as prominent electrodes for the hydrogen evolution reaction (HER). It was found that the Mo content in Ni-Mo alloys can be tuned from 30 to 78 at. \% by decreasing the molar ratio [Ni(II)]:[Mo(VI)] in the electrolyte from 1.0 to 0.25 and increasing the cathodic current density from 30 to $100 \mathrm{~mA} / \mathrm{cm}^{2}$. However, dense cracks and pits are formed due to hydrogen evolution at high current densities and that diminishes the catalytic activity of the coating for HER. Accordingly, smoother and crack-free Ni-54 at.\% Mo, Co-52 at.\% Mo and Fe-54 at.\% Mo alloys have been prepared at $30 \mathrm{~mA} / \mathrm{cm}^{2}$. Their catalytic behavior for HER has been investigated in a $30 \mathrm{wt} \% \mathrm{NaOH}$ solution at temperatures ranging from 25 to $65{ }^{\circ} \mathrm{C}$. A significant improvement of electrocatalytic activity with increasing bath temperature was noticed. The results showed that the sequence of electrocatalytic activity in alkaline media decreases in the following order: Co-52 at.\% Mo > Ni-54 at.\% Mo > Fe-54 at.\% Mo. These peculiarities might be linked with different catalytic behavior of formed intermetallics (and active sites) in electrodeposited alloys. The designed electrodeposited Mo-rich alloys have a higher catalytic activity than Mo and Pt cast metals.
\end{abstract}

Keywords: Ni-Mo; Co-Mo; Fe-Mo alloys; electrodeposition; hydrogen evolution reaction; electrocatalysis

\section{Introduction}

Hydrogen is a clean fuel and an energy carrier that can be used for energy conversion and storage and is considered as a possible substitute for fossil fuels [1]. Electrocatalytic water splitting offers an ideal approach for highly pure hydrogen production. However, despite the multitude of on-going research, the development of an optimized, cost-effective and sustainable catalyst, which possesses a high catalytic activity for hydrogen evolution reaction (HER) is still rather appealing. Commonly, the ability of a given metal to catalyze the HER is estimated based on the exchange current density (ECD), i.e., the current density in the absence of net electrolysis at zero overpotential (at formal equilibrium potential for hydrogen evolution reaction in the particular solution). It is known, that the higher the ECD, the lower the overvoltage that must be applied to create a significant current flow. Hence, elaborated electrocatalysts should manifest exchange current densities equivalent or analogous to the ECD of polycrystalline platinum $\left(\sim 1 \times 10^{-3} \mathrm{~A} / \mathrm{cm}^{2}\right.$ in alkaline electrolytes) [2]. 
A considerable part of research on the design of effective cathode materials for HER has been focused on Mo alloys with iron group metals $(\mathrm{Ni}, \mathrm{Co}, \mathrm{Fe})$ due to their superior catalytic performance in alkaline media [3-5], stability at elevated temperatures [6] and reasonable corrosion and oxidation resistance [7-10]. These characteristics, combined with good electrical conductivity, easy usage and reasonable price, are attractive parameters for selecting the cathode material for water electrolysis. It was revealed that the activity of the $\mathrm{Ni}-x$ at. $\% \mathrm{Mo}(12 \leq x \leq 29)$ alloy for HER is much higher than that of separate metallic nickel and molybdenum electrodes [11-15]. This phenomenon is attributed to the synergistic effect of Mo dispersed in the Ni matrix, which increases the real surface area of the electrode $[12,16]$. In addition, the enhancement of the catalytic activity for the HER of the Ni-15 at.\% Mo alloy was ascribed to the modification of electron density in d-orbitals upon alloying nickel with molybdenum [17]. In other words, this model implies that some of the electrons of the iron group metal (Ni, Fe, $\mathrm{Co}$ ) with more filled d-bands are shared with Mo having less-filled d-orbitals. This leads to maximal bond strength and stability of the intermetallic alloy phases $[18,19]$.

Commonly, Mo alloys with iron group metals (Ni, $\mathrm{Co}, \mathrm{Fe})$ can be synthesized by applying mechanical alloying [3,20-22], powder metallurgy [11,23,24], spraying [25] and laser cladding techniques [26]. However, fabrication processes in aqueous media are often considered as simpler, cheaper and more environmentally friendly fabrication methods than those requiring sophisticated apparatus, volatile and corrosive chemicals and extra energy that must be incurred to keep the system in a liquid state. Thus, molybdenum can be successfully co-electrodeposited in the presence of iron group metal ions (Ni(II), $\mathrm{Co}(\mathrm{II}), \mathrm{Fe}(\mathrm{II}))$ and appropriate complexing agents from an aqueous electrolyte. It is assumed that the molybdate ions are reduced to molybdenum oxide or hydroxide, which in the presence of iron group metal (Ni, Fe or $\mathrm{Co}$ ) species allows the formation of the corresponding binary alloy deposits. The effective Mo alloys electrodeposition with iron group metals were carried out from citrate [3,5,7,27], citrate-ammonia [10,12], citrate-gluconate [28], ammonia [29] and pyrophosphate $[30,31]$ aqueous electrolytes.

Moreover, it was claimed that $\mathrm{Ni}-\mathrm{Mo}$ electrodes show higher electrocatalytic activity than other Ni-based binary alloys such as $\mathrm{Ni}-\mathrm{Co}, \mathrm{Ni}-\mathrm{Fe}, \mathrm{Ni}-\mathrm{Zn}$ and $\mathrm{Ni}-\mathrm{Cr}[5,29]$. For a given reason, the fabrication of $\mathrm{Ni}-\mathrm{Mo}$ alloys possessing the highest activity for effective hydrogen production was the target for the vast research in the last decades. There are numerous reports certifying that the catalytic activity for hydrogen evolution is qualitatively proportional to the Mo content in Mo-based alloys [11,13,17]. Therefore, researchers' efforts were directed to optimize the plating bath vs. deposition conditions in order to obtain Mo-rich alloys as effective catalysts for the HER. It was shown that electrodeposition from ammonia based aqueous solutions produces Mo alloys with up to $\sim 41$ at.\% of Mo [32-36]. Coatings containing more than 40 at.\% Mo have been electrodeposited from ammonium-citrate solution in the presence of imidazolium-based ionic liquids as an additive [37]. Ammonia is frequently added to improve the cathode current efficiency, however, there is also some data about its effect on decreasing the Mo content in bimetallic Mo system with iron group metal (Ni, $\mathrm{Co}, \mathrm{Fe}$ ) [34]. Thus, despite the reduced current efficiency, typically ammonia-free electrolytes are used for the preparation of Mo-rich coatings, e.g., the Fe-Mo electrodes containing up to 59 at. $\%$ of Mo have been prepared from a pyrophosphate bath [38,39]. Binary Fe-Mo alloys with 49 at. $\%$ of Mo have been electrochemically formed from an aqueous trisodium nitrilotriacetate bath [40]. A considerable increase in Mo content, i.e., up to 70 at. \%, can be caused by the addition of Mo powder to the electrolyte [41]. In addition, it has been noted that Mo content in alloys composition can be increased by carrying out the electrodeposition under the pulse current mode [42]. The highest Mo content, 74 at.\%, achieved so far by induced electrodeposition in aqueous citrate electrolyte was reported for a Ni-Mo alloy [43].

Therefore, based on the mentioned above, the given research was focused on the electrodeposition of Ni-, Co- and Fe- Mo-rich alloys from a highly saturated ammonium acetate bath. The electrolyte's composition given in Reference [44] was adapted for the electrodeposition of binary Mo-containing alloys. In order to determine the influence of the nature of the iron group metal on the catalytic activity of target coatings (Ni-, $\mathrm{Co}$ - and Fe- Mo-rich alloys) the electrochemical conditions were tuned 
in such way to ensure deposition of alloys with similar content of Mo. The catalytic activity of the electrochemically fabricated Mo-based alloy electrodes for the HER was explored in a $30 \mathrm{wt} . \% \mathrm{NaOH}$ solution. In order to compare the electrochemical activity with other typical electrode materials, experiments were also performed using bare platinum electrode (same geometrical area) under the same conditions.

\section{Materials and Methods}

\subsection{Mo-Rich Alloys Electrodeposition}

Mo-rich alloys, namely Ni-Mo, Co-Mo and Fe-Mo, were prepared from highly saturated ammonium acetate electrolytes (Table 1) based on bath composition proposed in Reference [44] for Mo films deposition. All solutions were prepared from chemicals of analytical grade (A.R.) dissolved in demineralized water. The electrodeposition of coatings was carried out at $30^{\circ} \mathrm{C}$ in order to lower the viscosity of the concentrated solutions and to avoid salt precipitation. $\mathrm{Cu}$ rod (surface area of $\left.1 \mathrm{~cm}^{2}\right)$, platinum sheet $\left(3 \times 7 \mathrm{~cm}^{2}\right)$ and a saturated $\mathrm{Ag} / \mathrm{AgCl}$ electrode were used as a working, counter and reference electrodes, respectively. Prior to the electrodeposition, $\mathrm{Cu}$ rods were washed and cleaned in an ultrasonic bath for 6-7 min and etched in an $\mathrm{HNO}_{3}: \mathrm{CH}_{3} \mathrm{COOH}: \mathrm{H}_{3} \mathrm{PO}_{4}$ (1:1:1) solution at $60{ }^{\circ} \mathrm{C}$. The thickness of the prepared Mo alloy coatings with iron group metals was calculated from gravimetric and elemental analysis data. Further, the electrocatalytic activity for the HER in $30 \mathrm{wt} . \%$ $\mathrm{NaOH}$ of fabricated cathodes has been investigated.

Table 1. Composition of electrolytes for Ni-Mo (Baths No. 1-3), Co-Mo (Bath No. 4) and Fe-Mo (Bath No. 5) coatings electrodeposition.

\begin{tabular}{cccccccc}
\hline Bath & $\mathrm{CH}_{3} \mathrm{CO}_{2} \mathrm{~K}$ & $\mathrm{CH}_{3} \mathrm{CO}_{2} \mathrm{NH}_{4}$ & $\left(\mathrm{NH}_{4}\right)_{2} \mathrm{MoO}_{4}$ & $\mathrm{NiSO}_{4} \cdot 7 \mathrm{H}_{2} \mathrm{O}$ & $\mathrm{CoSO}_{4} \cdot 7 \mathrm{H}_{2} \mathrm{O}$ & $\mathrm{FeSO}_{4} \cdot 7 \mathrm{H}_{2} \mathrm{O}$ & $\mathrm{pH}$ \\
\hline 1 & & & & $0.001 \mathrm{M}$ & & & \\
2 & & & & $0.002 \mathrm{M}$ & - & - & 8.2 \\
3 & $10.2 \mathrm{M}$ & $10.4 \mathrm{M}$ & $0.004 \mathrm{M}$ & $0.004 \mathrm{M}$ & & - & \\
4 & & & & - & $0.002 \mathrm{M}$ & & 8.3 \\
5 & & & & - & - & $0.002 \mathrm{M}$ & 8.3 \\
\hline
\end{tabular}

\subsection{Morphological and Structural Study}

The surface morphology and chemical composition of the prepared Mo-based deposits were examined with the scanning electron microscope (SEM, Hitachi TM3000, Tokyo, Japan) equipped with an INCA energy dispersive $X$-ray spectroscopy detector (EDS, Oxford Instruments, Buckinghamshire, $\mathrm{UK}$ ) at an accelerating voltage of $20 \mathrm{kV}$, respectively. Based on the chemical composition of the obtained alloys, the current efficiency (CE) was calculated according to the Faradays' law:

$$
\mathrm{CE}(\%)=\frac{F m}{I t}\left[\frac{x_{i} n_{i}}{M_{i}}+\frac{x_{\mathrm{Mo}} \cdot n_{\mathrm{Mo}}}{M_{\mathrm{Mo}}}\right] \times 100 \%
$$

where $F$ is Faradays constant (96485 C); $m$ is the weight of the electrodeposit (g); $I$ is an applied current (A); $t$ is the time of electrodeposition (s); $x_{i}, n_{i}, M_{i}$ is the content (wt.\%), electrons transferred per ion, and molecular weight $(\mathrm{g} / \mathrm{mol})$ of $\mathrm{Ni}$, Co or Fe, respectively; $x_{\mathrm{Mo}}, n_{\mathrm{Mo}}, M_{\mathrm{Mo}}$ is the content, wt.\%, electrons transferred per particular ion, respectively; molecular weight of Mo.

The structure of the electrodeposited alloys was investigated by X-ray diffraction (XRD) methods (Rigaku MiniFlex II, Tokyo, Japan). XRD patterns were produced with $\mathrm{Cu}$ K $\alpha$ radiation (1.5406 $\AA$ ) in $2 \theta$ scanning mode from 20 to $100^{\circ}$ with a step of $0.01^{\circ}$. 


\subsection{Electrochemical Measurements}

The voltammetric measurements for the evaluation of the kinetic parameters of Mo-rich alloys for the HER were performed in a $30 \mathrm{wt} . \% \mathrm{NaOH}$ solution at several temperatures $\left(25-65^{\circ} \mathrm{C}\right.$, with the increment of $10^{\circ} \mathrm{C}$ ) in a thermostatic cell. A platinum wire was used as an auxiliary electrode and a saturated $\mathrm{Ag} / \mathrm{AgCl}$ electrode was used as the reference electrode. All potentials are given with respect to the $\mathrm{Ag} / \mathrm{AgCl}$ reference electrode. Potentiodynamic polarization hydrogen evolution curves were recorded at the sweep rate of $2 \mathrm{mV} / \mathrm{s}$. The cathode potential was scanned from its open circuit potential (OCP) up to $-1 \mathrm{~V}$. Voltammetric curves were recorded using a potentiostat/galvanostat AUTOLAB equipped with GPES software (version 4.9). Extrapolation of the polarization curves obtained at different temperatures, in the coordinates $\lg i-\eta$ to value $\eta=0$ give the possibility to determine the $\operatorname{ECD}\left(i_{0}\right)$. The overvoltage, $\eta$, was calculated from the following equation:

$$
\begin{gathered}
\eta=E-E_{\mathrm{r}} \\
E_{\mathrm{r}}=-\left(\frac{2.3 R T}{F}\right) \mathrm{pH}
\end{gathered}
$$

where $\eta$ is an overpotential of the HER $(V), E$ is an experimental potential value at which the reaction takes place $(\mathrm{V}) ; E_{\mathrm{r}}$ is the reversible potential value calculated from the Nernst equation $(\mathrm{V}), R$ is the universal gas constant $(8.314472 \mathrm{~J} / \mathrm{K} \mathrm{mol}) ; T$ is the temperature $(\mathrm{K}) ; F$ is the Faraday constant $(96,485 \mathrm{~J} / \mathrm{mol})$.

For the calculation of overpotentials at temperatures other than $25^{\circ} \mathrm{C}$, the tabulated data [45] of the temperature dependence of the potential of the saturated $\mathrm{Ag} / \mathrm{AgCl}$ electrode vs. the hydrogen electrode, were used.

\section{Results and Discussion}

\subsection{Design of Mo-Rich Alloys Coatings}

The high percentage of molybdenum in Mo-based alloy electrodeposits leads commonly to the growth of the ECD value but also has a positive influence on their corrosion resistance and microhardness [10]. On the other hand, the electrodeposition of coatings having a very high molybdenum content ( $>38$ at.\% of Mo) is more sensitive to side reactions, namely the evolution of hydrogen, which can lead to the appearance of a dense net of cracks, bumps and small pits that diminish practical application of such coatings for the HER. Thus, the first step of the given research was dedicated to the selection of the optimum electrochemical conditions (bath chemistry, applied current density) in order to obtain high-quality Mo-rich alloys with a reasonable deposition rate. The first investigated system was Ni-Mo (Table 1, Baths 1-3) since a high amount of publications have reported $[15,46,47]$ that the Ni-Mo alloy is the most promising non-noble catalysts for the HER among other refractory metal-based electrodes.

Previously, it was shown that if the ratio $[\mathrm{Ni}(\mathrm{II})]:[\mathrm{Mo}(\mathrm{VI})]$ is approaching 10 , the amount of Mo in the Ni-Mo deposit decreases dramatically from 65 to 20 at.\% [48]. Therefore, in order to obtain Mo-rich alloys, the ratio was kept at $0.25,0.5,1.0$. Another parameter, which influences the refractory metal content in the alloys is the applied current density. Based on a preliminary study, two cathodic current densities, namely 30 and $100 \mathrm{~mA} / \mathrm{cm}^{2}$, have been chosen for electrodeposition of Mo-rich alloys.

Taking these parameters into account, the dependence of Mo content on the $[\mathrm{Ni}(\mathrm{II})]$ :[Mo(VI)] ratio and the cathodic current density was evaluated (Table 2). Namely, as it was anticipated, the amount of Mo in the alloys decreases from $\sim 85$ to 36 at. \% as the Ni(II) increased in the bath. Here it should be mentioned, that only the content of the metallic phase was taken into account for the evaluation regardless of the ambiguous values of oxygen and other light elements detected by the EDS analysis. The highest content of molybdenum in the Ni-Mo deposits, around 85 at.\%, was achieved at a $[\mathrm{Ni}(\mathrm{II})] /[\mathrm{Mo}(\mathrm{VI})]$ ratio equal to 0.25 in the plating bath. This Mo amount is significantly higher 
in comparison with previous works reported for Ni-Mo alloys obtained from aqueous electrolytes and is close to that found for Ni-Mo alloys prepared by metallurgical [11] or mechanical alloying techniques [49]. In order to reveal the interdependencies between bath chemistry and applied current densities, partial current densities (PSD) for $\mathrm{Ni}_{\mathrm{PCD}}, \mathrm{MoPCD}$ reduction and hydrogen evolution were also evaluated based on Faraday's law (Table 2).

Table 2. Dependence of composition, morphology and partial current densities of electrodeposited $\mathrm{Ni}-\mathrm{Mo}$ alloys on the $[\mathrm{Ni}(\mathrm{II})]:[\mathrm{Mo}(\mathrm{VI})]$ ratio and applied cathodic current density. Molybdenum at.\% content is specified on the SEM images.

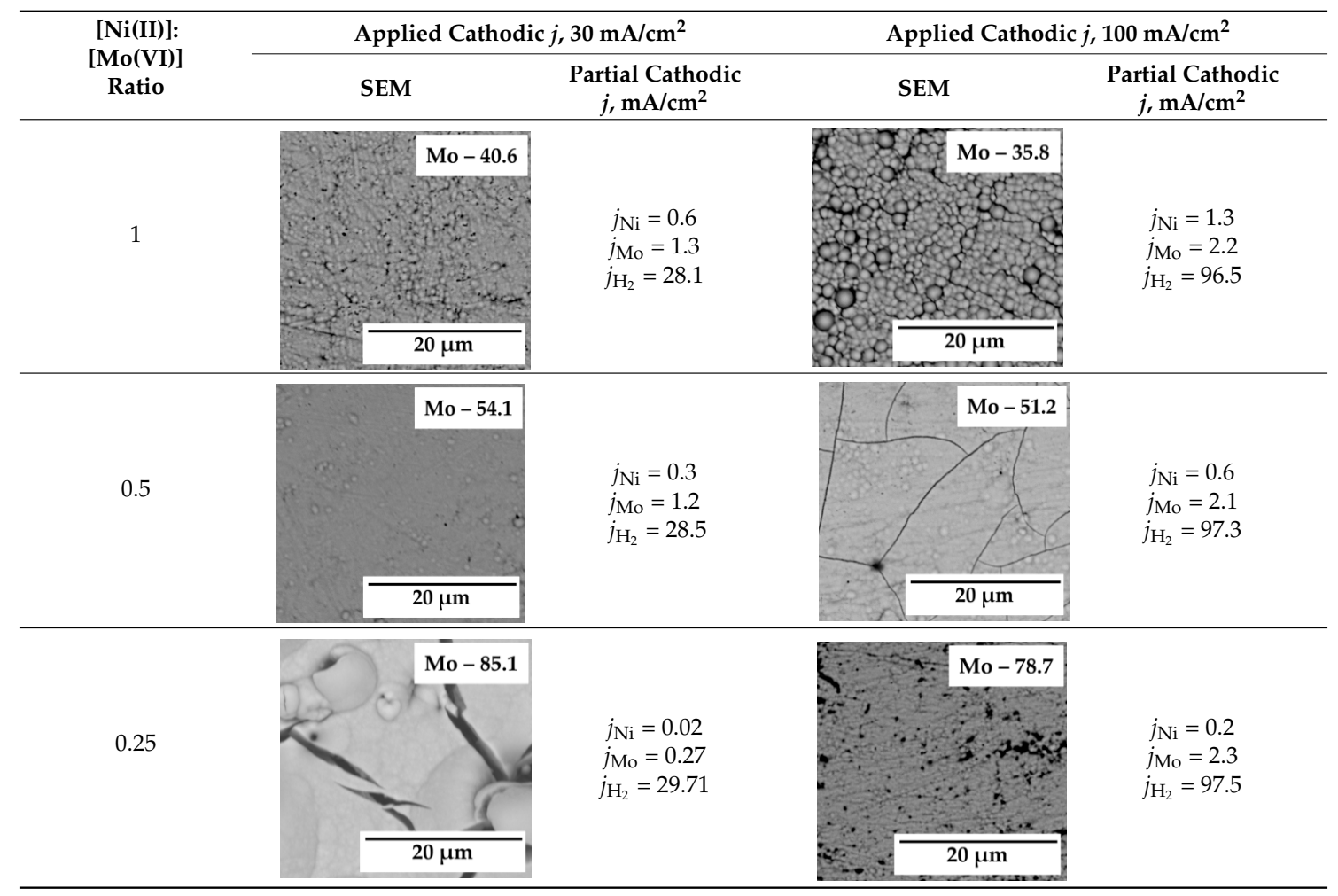

Namely, the increase of the $[\mathrm{Ni}(\mathrm{II})]:[\mathrm{Mo}(\mathrm{VI})]$ ratio increases the $\mathrm{Ni}_{\mathrm{PCD}}$ and consequently $\mathrm{Ni}$ content in the deposit the higher applied current density (overpotential) accelerates the reduction of $\mathrm{Ni}(\mathrm{II})$ rather than $\mathrm{Mo}(\mathrm{VI})$ compounds. The side reaction is accelerated by a higher Mo content in the alloy that leads to the propagation of large micro-cracks, especially for Ni-Mo alloys deposited at a $[\mathrm{Ni}(\mathrm{II})] /[\mathrm{Mo}(\mathrm{VI})]$ ratio $\leq 0.5$ and having more than 50 at. $\%$ of Mo. Our results are in a good agreement with Reference [50], where it was shown that the cracks in the Ni-Mo alloys deposited from a citrate solution have been tracked at a Mo content higher than $\sim 30$ at. $\%$ but from an ammonium-citrate electrolyte [3] they appear even at lower Mo content ( 21 at.\%).

Hence, in order to obtain Mo-rich alloys without visible defects, the applied current density of $30 \mathrm{~mA} / \mathrm{cm}^{2}$ and a $[\mathrm{Ni}(\mathrm{II})]:[\mathrm{Mo}(\mathrm{VI})]$ ratio of 0.5 should be viewed as the optimum conditions. This ratio allows for a four times increase in the $\mathrm{Mo}_{\mathrm{PCD}}$ in comparison with the ratio of 0.25 . It suggests that the electroactive complex should contain both molybdenum and nickel species. At the higher ratio (higher $\mathrm{Ni}(\mathrm{II})$ concentration), the MoPCD does not change significantly but the Mo content in the alloy decreases (from 54 to 40 at.\%). Notably, at a current density of $100 \mathrm{~mA} / \mathrm{cm}^{2}$, the MoPCD is practically the same for all investigated $[\mathrm{Ni}(\mathrm{II})]$ :[Mo(VI)] ratios, suggesting that electroactive Mo-containing species under such conditions reaches saturation and has no significant effect on alloy electrodeposition. Furthermore, at a higher applied current density, an additional roughening due to the pronounced nodular structure of the coatings is obtained, that can be interconnected with abundant hydrogen evolution, which leads to cracks and holes on the surface (Table 2). On the one hand, in Reference [51], it was shown that the 
cracked surfaces are characterized by higher HER activity and ascribed to an increased surface area of the active centers due to the microcracks but on the other hand, a certain amount of the hydrogen enters the open pores (cracks) of the deposit and it starts peeling off around the pores. Hence, it is obvious that the application of such coatings in the industrial processes is not recommendable [30]. Moreover, due to high PCDs for hydrogen reduction, the current efficiency in all investigated cases is rather low $(<10 \%)$. This is a common characteristic for Ni-Mo co-deposition [52] that is associated with the formation of a mixed Mo oxides layer in the presence of an excess of $\mathrm{Mo}(\mathrm{VI})$ ions in the bath, which hinders the further reduction.

Accordingly, based on the experimental results obtained for Ni-Mo alloys, the following optimal conditions were adapted for electrodeposition of $\mathrm{Co}-\mathrm{Mo}$ and $\mathrm{Fe}-\mathrm{Mo}$ alloys: cathodic current density $30 \mathrm{~mA} / \mathrm{cm}^{2}$ and $[\mathrm{Me}(\mathrm{II}) / \mathrm{Mo}(\mathrm{VI})]=0.5$. This allowed for the electrodeposition of Mo-rich coatings (Co-52 at.\% Mo and Fe-54 at.\% Mo) coupled with suitable morphology (crack-free coatings with a less rough globular surface) and to evaluate the influence of iron group metal on the catalytic activity for HER in alkaline media. The obtained morphology of Mo-rich alloys was quite similar regardless of the iron group metal (Figure 1).
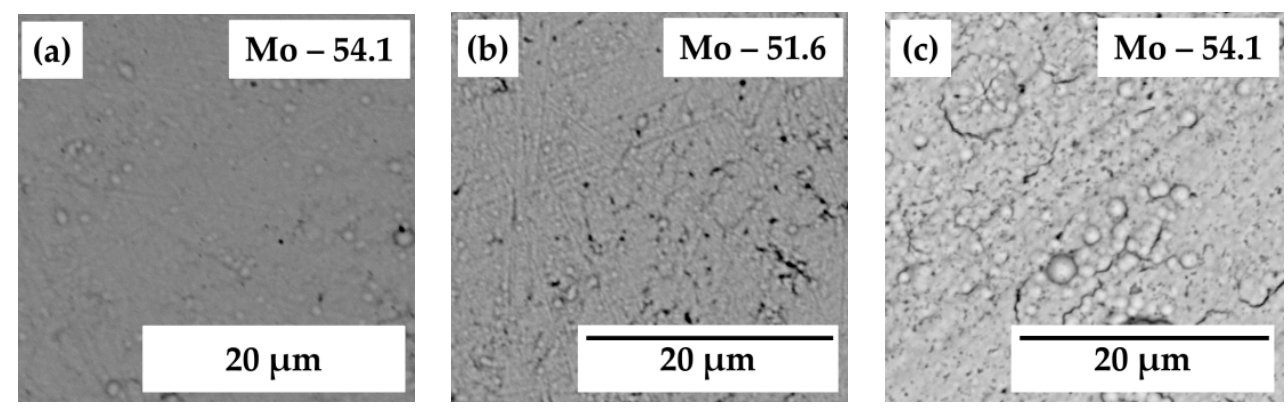

Figure 1. SEM images of electrodeposited at $30 \mathrm{~mA} / \mathrm{cm}^{2}$ and $[\mathrm{Me}(\mathrm{II})] /\left[\mathrm{MoO}_{4}{ }^{2-}\right]=0.5$ coatings: $\mathrm{Ni}-\mathrm{Mo}$ (a), Co-Mo (b) and Fe-Mo (c). The time of electrolysis was $1 \mathrm{~h}$ and the thickness of all deposits was $\sim 10 \mu \mathrm{m}$.

The structure and crystallite size was evaluated by XRD analysis. A characteristic broad peak at $2 \theta=43^{\circ}-44^{\circ}$ was obtained for Ni-54 at.\% Mo and is depicted in Figure 2a. According to the thermodynamic equilibrium data, the solubility limit of Mo in the fcc Ni structure at room temperature is $\sim 17$ at.\%. When the Mo content exceeds this limit, an amorphous microstructure can be noticed and the formation of intermetallic $\mathrm{Ni}_{4} \mathrm{Mo}, \mathrm{Ni}_{3} \mathrm{Mo}$, NiMo compounds becomes possible for $\mathrm{Ni}-\mathrm{Mo}$ alloys having $>25$ at.\% of Mo [31,53]; a line with a solid solution of Ni in Mo. It is also known that the broadening of the XRD peak is related to the refinement of crystallite size that typically occurs with an increasing Mo content [31]. According to the literature, the mean crystallite size of Ni-Mo coatings can decrease from 50 to $2 \mathrm{~nm}$ by increasing the Mo content from 1 to 38 at. $\%$, respectively $[35,37,54]$. This corresponds to a crystallite size of the investigated Ni-Mo coatings as small as $\sim 2 \mathrm{~nm}$. Notably, $\mathrm{Ni}-\mathrm{Mo}$ deposits consisting of such small crystallites can have a lower overpotential for hydrogen evolution due to the larger concentration of crystal lattice defects and dislocations, which are considered as active centers for HER [12,19]. 


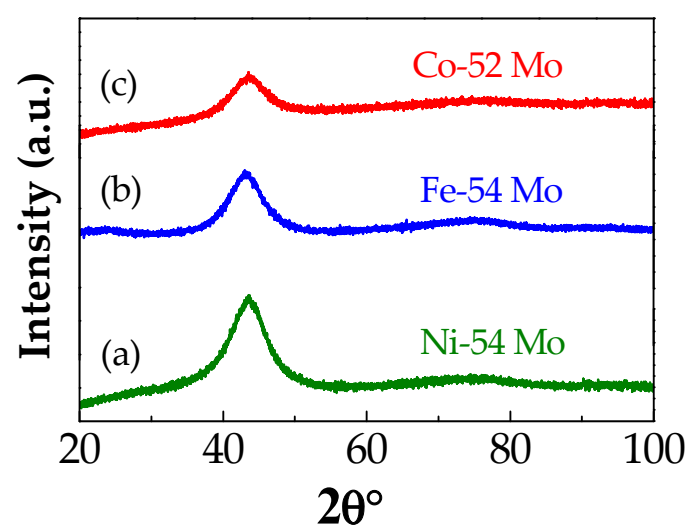

Figure 2. XRD pattern for: (a) Ni-54 Mo, (b) Fe-54 Mo and (c) Co-52 Mo electrodeposits (composition is given in at.\%).

The XRD patterns for Fe-54 at.\% Mo and Co-52 at.\% Mo alloys showed the analogous crystalline structure to the Ni-54 at.\% Mo coating (Figure 2b,c). Since the presence of one broad peak in the X-ray diffraction patterns makes it difficult to interpret the results, it can be only proposed that a mixture of Mo solid solution in the iron group metal and corresponding intermetallic compounds were formed. For the Fe-Mo (also Fe-W) system, the Mössbauer spectroscopy supports this presumption and suggests that deposits having more than 17 at.\% of refractory metal consists of a mixture of molybdenum solid solution in $\alpha$-Fe and intermetallic phases, e.g., $\mathrm{Fe}_{3} \mathrm{Mo}, \mathrm{Fe}_{2} \mathrm{Mo}$ [55,56]. In the case of the Co-Mo alloy, some of the studies reported that a Mo solid solution in cobalt and intermetallic $\mathrm{Co}_{3} \mathrm{Mo}$ is formed [36,57].

The different intermetallic phases should have an impact on their activity for the HER. It was emphasized that the maximum electrocatalytic activity could be achieved for intermetallic phases of highest symmetry and minimal entropy, such as Laves phases or $\mathrm{A}_{3} \mathrm{~B}$ types $\left(\mathrm{Co}_{3} \mathrm{Mo}, \mathrm{Ni}_{3} \mathrm{Mo}\right.$, $\mathrm{Fe}_{3} \mathrm{Mo}$ ) and the Brewer theory for intermetallic bonding predicts as the most stable systems [58]. Thus, it was reported that films consisting of a $\mathrm{Co}_{3}$ Mo phase (for $\mathrm{Co}-x$ at. $\% \mathrm{Mo}, 18 \leq x \leq 28$ ) have the best electrocatalytic properties among other Co-Mo alloys having lower molybdenum contents [59]. Furthermore, in Reference [60], it was concluded that $\mathrm{Co}_{3} \mathrm{Mo}$ intermetallic compounds are more stable in a hot alkaline solution than other Co-Mo phases. Similarly, in the case of the Fe-Mo alloy system, the lowest overvoltage for hydrogen evolution at a current density of $200 \mathrm{~mA} / \mathrm{cm}^{2}$ has been observed for the $\mathrm{Fe}-47$ at.\% Mo sample with a predominant $\mathrm{Fe}_{3} \mathrm{Mo}$ intermetallic compound phase [38].

\subsection{Catalytic Behavior}

The electrocatalytic activity for hydrogen evolution in $30 \mathrm{wt} . \% \mathrm{NaOH}$ of $\mathrm{Ni}-\mathrm{Mo}, \mathrm{Co}-\mathrm{Mo}$ and Fe-Mo samples containing 52-54 at.\% of Mo in their composition was evaluated using a linear scan voltammetry method that allows for the determination of the apparent exchange current densities. Polarization curves and semi-logarithmic coordinates of all chosen systems obtained at $25^{\circ} \mathrm{C}$ are presented in Figure 3. In order to compare the catalytic behavior of Mo-rich Ni-, Co-, Fe-Mo coatings, the cast Mo and Pt electrodes were used. Table 3 summarizes the calculated apparent exchange current densities $\left(i_{0}\right)$, the overpotentials at a selected current density of $200 \mathrm{~mA} / \mathrm{cm}^{2}\left(\eta_{0.2}\right)$ and the current densities obtained at an overpotential of $0.3 \mathrm{~V}\left(i_{0.3}\right)$; calculated Tafel slopes $\left(b_{\mathrm{c}}\right)$. 

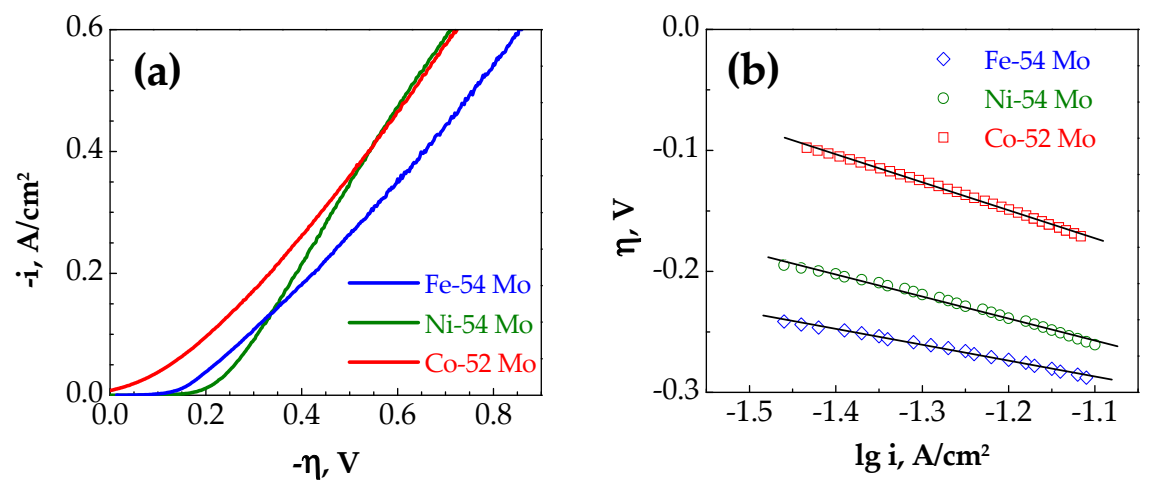

Figure 3. Cathodic polarization curves of (a) Mo-rich electrodeposits in $30 \mathrm{wt} . \% \mathrm{KOH}$ at $25^{\circ} \mathrm{C}$ and (b) plots in semi-logarithmic coordinates. The scan rate was $2 \mathrm{mV} / \mathrm{s}$ (composition is given in at.\%).

Table 3. Calculated apparent exchange current densities $\left(i_{0}\right)$, Tafel slopes $\left(b_{\mathrm{c}}\right)$, overpotentials $\left(\eta_{i}\right)$ at $i=0.3 \mathrm{~A} / \mathrm{cm}^{2}$ and current densities $\left(i_{\eta}\right)$ at $\eta=-0.3 \mathrm{~V}$ for hydrogen evolution different electrodes (composition is given in at.\%).

\begin{tabular}{cccccc}
\hline \multirow{2}{*}{ Parameter } & \multicolumn{5}{c}{ Electrode } \\
\cline { 2 - 6 } & Ni-54 Mo & Co-52 Mo & Fe-54 Mo & Mo & Pt \\
\hline$i_{\mathrm{O}}\left(\mathrm{mA} / \mathrm{cm}^{2}\right)$ & 0.62 & 1.90 & 0.23 & $2.90 \times 10^{-5}$ & 2.63 \\
$b_{\mathrm{c}}(\mathrm{mV} / \mathrm{dec})$ & 128 & 132 & 152 & 231 & 122 \\
$\eta_{i}(\mathrm{~V})$ & 0.46 & 0.43 & 0.54 & 0.67 & 0.48 \\
$i_{\eta}\left(\mathrm{A} / \mathrm{cm}^{2}\right)$ & $9.1 \times 10^{-2}$ & $1.8 \times 10^{-1}$ & $9.3 \times 10^{-2}$ & $5.4 \times 10^{-4}$ & $8.2 \times 10^{-2}$ \\
\hline
\end{tabular}

Binary Mo alloy cathodes possess $10^{5}$ times higher apparent exchange current densities than cast Mo, thus are more active for the HER. However, all alloys demonstrated lower apparent exchange current densities for the HER at $25^{\circ} \mathrm{C}$ in comparison with a bare Pt electrode. However, the overpotentials required to obtain current densities of $300 \mathrm{~mA} / \mathrm{cm}^{2}$ and current densities at $-0.3 \mathrm{~V}$ for active bimetallic Mo alloys ware similar to those determined for $\mathrm{Pt}$, making them competitive electrodes for hydrogen production. Notably, as it was mentioned above, the nature of the iron group metal affects the catalytic activity for the HER and the cathodic current density for the Co-52 at.\% Mo coating is higher in comparison to that of $\mathrm{Ni}-54$ at.\% and Fe-54 at.\% Mo, thus indicating the best catalytic performance among the synthesized electrodes, which is consistent with the lowest $\eta_{0.2}$ and $i_{0.3}$ values.

It is well known that the lower Tafel slope implies a lower electrochemical electrode polarization during the HER process, particularly at a high current density. The values of the Tafel slope for $\mathrm{Ni}-54$ at.\% Mo and Co-52 at.\% Mo deposits under high polarization conditions are $128 \mathrm{mV} / \mathrm{s}$ and $132 \mathrm{mV} / \mathrm{dec}$, respectively. Meanwhile, the Tafel slope for Fe-54 at.\% Mo under these conditions shifted to more positive values, i.e., increased up to $152 \mathrm{mV} / \mathrm{dec}$ and it can be related to the higher iron affinity to the air and the presence of a thin oxide film on the surface that is characterized by a lower conductivity that impedes the electron transfer rate [15].

An improvement of catalytic activity for the HER with the operation temperature, as is desired for practical industrial alkaline electrolysis has been reported [36,42]. Accordingly, in the present study, the electrodeposited alloy electrodes were tested at temperatures ranging from 25 to $65{ }^{\circ} \mathrm{C}$ by applying $10{ }^{\circ} \mathrm{C}$ increments. A general comparison of the performance of electrodeposited Ni-54 at.\% Mo, $\mathrm{Fe}-54$ at.\% Mo, Co-52 at.\% Mo and cast separate metals in the temperature range $25-65{ }^{\circ} \mathrm{C}$ is given in Figure 4. The apparent exchange current densities were calculated from the linear region at low overpotential values and are presented in Table 4 . As it was expected, the electrocatalytic activity of Ni-54 at.\% Mo, $\mathrm{Fe}-54$ at. $\%$ Mo and Co-52 at.\% Mo is significantly higher than cast Mo in the whole tested temperature range. Moreover, the results suggest that at an elevated temperature $\left(>35^{\circ} \mathrm{C}\right)$ Mo-rich alloys have a more prominent HER outperformance than Pt investigated in our 
laboratory. Although the HER activity, namely $\mathrm{i}_{0}$, was found to increase with temperature, the Tafel slopes for the Mo-based alloys remained almost constant and varied in the range of $120-150 \mathrm{mV} / \mathrm{dec}$. This phenomenon has been discussed in terms of the entropic contribution towards free energy of activation [61]. Among all investigated systems, the Co-52 at.\% Mo electrode demonstrates the best performance towards the HER, particularly at temperatures higher than $45^{\circ} \mathrm{C}$. These results correspond well with findings published in Reference [62] where it was confirmed that Co-Mo co-deposits are characterized by a higher catalytic activity and stability in alkaline water electrolysis than $\mathrm{Ni}-\mathrm{Mo}, \mathrm{Co}-\mathrm{W}$ and $\mathrm{Ni}-\mathrm{W}$ alloy electrodes. Moreover, in Reference [63], it was shown that catalytic activity depends on the metal-hydrogen bond strength and absorption sites in the alloy available to hydrogen and thus the electrochemically charged $\mathrm{H}$ content decreases in the series of $\mathrm{Co}-\mathrm{Mo}>\mathrm{Co}-\mathrm{W}$ $>\mathrm{Ni}-\mathrm{Mo}$. Furthermore, comparing $\mathrm{Co}-\mathrm{Mo}, \mathrm{Co}-\mathrm{W}$ and Ni-Mo electrodeposits, the thermal desorption of hydrogen occurs at the lowest temperature on Co-Mo showing a faster recombination step of $\mathrm{H}$ atoms possible on this alloy, thus improving its electrocatalytic performance [63].
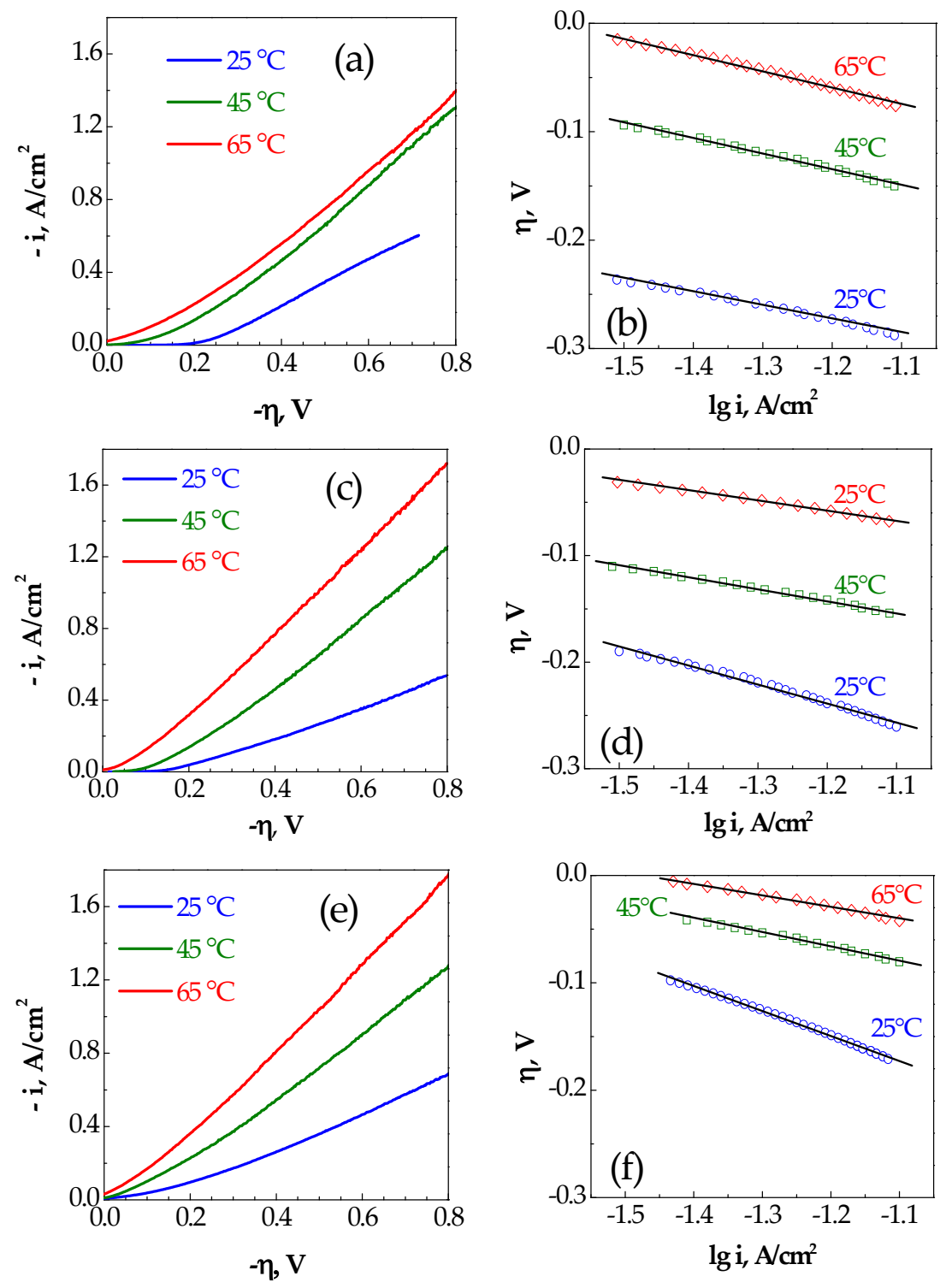

Figure 4. Effect of temperature on cathodic polarization curves at Ni-54 Mo (a), Fe-54 Mo (c), Co-52 Mo (e) electrodeposits in $30 \mathrm{wt} . \% \mathrm{KOH}$ at different temperatures and plots in semi-logarithmic coordinates for Ni-54 Mo (b), Fe-54 Mo (d), Co-52 Mo (f) electrodes. The scan rate was $2 \mathrm{mV} / \mathrm{s}$ (composition is given in at.\%). 
Table 4. Experimental values of the apparent exchange current $\left(i_{0}\right.$, in $\left.\mathrm{mA} / \mathrm{cm}^{2}\right)$ and Tafel slopes $\left(b_{\mathrm{c}}\right.$, in $\left.\mathrm{mV} / \mathrm{dec}\right)$ for Ni-54 Mo, Co-52 Mo and Fe-54 Mo alloy electrodes at different temperatures (composition is given in at.\%).

\begin{tabular}{|c|c|c|c|c|c|c|c|c|c|c|}
\hline \multirow{3}{*}{ Sample } & \multicolumn{10}{|c|}{ Measurement temperature $\left({ }^{\circ} \mathrm{C}\right)$} \\
\hline & \multicolumn{2}{|l|}{25} & \multicolumn{2}{|l|}{35} & \multicolumn{2}{|c|}{45} & \multicolumn{2}{|l|}{55} & \multicolumn{2}{|l|}{65} \\
\hline & $i_{0}$ & $b_{\mathrm{c}}$ & $i_{0}$ & $b_{\mathrm{c}}$ & $i_{0}$ & $b_{\mathrm{c}}$ & $i_{0}$ & $b_{\mathrm{c}}$ & $i_{0}$ & $b_{\mathrm{c}}$ \\
\hline $\mathrm{Ni}-54 \mathrm{Mo}$ & 0.62 & 128 & 3.21 & 128 & 7.32 & 119 & 1.47 & 116 & 25.4 & 123 \\
\hline $\mathrm{Fe}-54 \mathrm{Mo}$ & 0.23 & 152 & 0.99 & 148 & 4.33 & 142 & 5.83 & 139 & 14.6 & 145 \\
\hline Co-52 Mo & 1.90 & 132 & 9.53 & 130 & 17.1 & 128 & 32.0 & 121 & 46.2 & 119 \\
\hline Mo & $2.9 \times 10^{-2}$ & 231 & $8.3 \times 10^{-2}$ & 220 & $1.9 \times 10^{-1}$ & 220 & $2.1 \times 10^{-1}$ & 215 & $2.3 \times 10^{-1}$ & 221 \\
\hline $\mathrm{Pt}$ & 2.63 & 122 & 3.68 & 129 & 6.51 & 120 & 2.63 & 125 & 11.5 & 125 \\
\hline
\end{tabular}

In many previous publications the Ni-Mo alloy coatings are characterized by a lower overpotential value, as compared to the Co-Mo [14]. Though, there is also some information suggesting that Co-Mo coatings have a better catalytic activity for the HER compared to Ni-Mo deposits [62,64]. At the first glance, these controversial results could be attributed to the different alloy preparation techniques that are capable of yielding an uneven composition, morphology and structure of the prepared samples and thus, directly influence the catalytic properties of the samples. However, the clear tendency between the nature of the iron group metal effect during alloying with Mo and catalytic behavior also cannot be easily defined even for the Ni-Mo, Co-Mo and Fe-Mo cathodes fabricated using the same electrodeposition technique (Table 5). As it can be seen, the exchange current densities, even for alloys having a similar chemical composition, vary depending on the selected alkaline media and temperature.

In general, the present study shows the catalytic activity for the Ni-Mo alloy is comparable to previously reported samples under similar experimental conditions (Figure 5). Moreover, in the case of the Co-Mo and Fe-Mo system, the apparent exchange current density calculated in our work is significantly higher than it was expected from other authors observations (the corresponding columns are not given in the figure due to a significantly lower value). This could be attributed to the more concentrated alkaline media and higher temperature used in the present study.

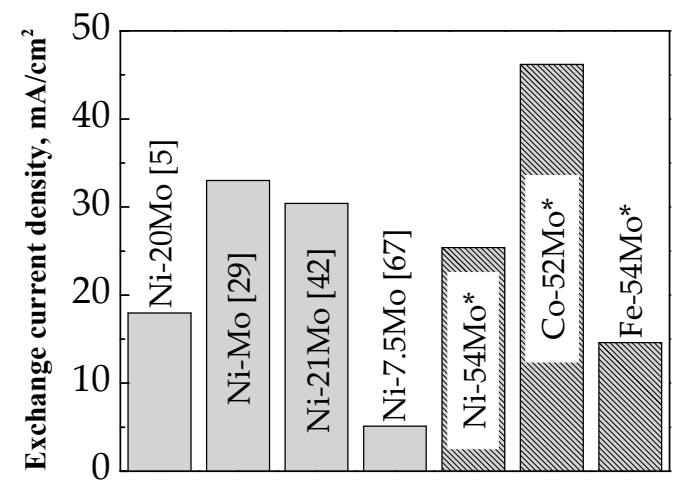

Figure 5. The comparison of apparent exchange current densities $\left(i_{0}\right)$ towards the HER on Mo alloys with iron group metals determined in this study $\left({ }^{*}\right)$ with the published data. The experiments were performed in $\mathrm{NaOH}$ at $60-65^{\circ} \mathrm{C}$. The composition of alloys is given in at. $\%$.

Notably, the Fe-Mo coating demonstrates lower exchange current densities for the HER in an alkaline environment among other electrodes investigated in this study. This may be related to the higher iron affinity to the air by forming an oxide, hydroxide, or mixed film that physically separates the metal surface from the electrolyte. 
Table 5. Comparison of the HER apparent exchange current density values, $i_{0}$, extracted from the published data for electrodeposited Ni-Mo, Co-Mo and Fe-Mo alloy electrodes.

\begin{tabular}{|c|c|c|c|c|}
\hline Sample & Mo content (at.\%) & Media & $i_{0}\left(\mathrm{~mA} / \mathrm{cm}^{2}\right)$ & Reference \\
\hline \multirow{9}{*}{$\mathrm{Ni}-\mathrm{Mo}$} & 26 & $8.25 \mathrm{M} \mathrm{NaOH}, 85^{\circ} \mathrm{C}$ & 44.4 & [4] \\
\hline & 20 & $6 \mathrm{M} \mathrm{KOH} ; 80^{\circ} \mathrm{C}$ & 18.62 & [5] \\
\hline & 33.8 & $7 \mathrm{M} \mathrm{KOH}, 25^{\circ} \mathrm{C}$ & 2.8 & [19] \\
\hline & - & $7 \mathrm{M} \mathrm{KOH}, 80^{\circ} \mathrm{C}$ & 55.24 & [29] \\
\hline & 25 & $2 \mathrm{M} \mathrm{NaOH}, 30^{\circ} \mathrm{C}$ & $3.1 \times 10^{-2}$ & [32] \\
\hline & 20.8 & $11 \mathrm{M} \mathrm{NaOH} ; 80^{\circ} \mathrm{C}$ & 42.4 & [42] \\
\hline & 29.8 & $1 \mathrm{M} \mathrm{NaOH}, 30^{\circ} \mathrm{C}$ & 11.1 & [65] \\
\hline & 27.5 & $1 \mathrm{M} \mathrm{KOH}$ & $3.18 \times 10^{-3}$ & [66] \\
\hline & 7.5 & $6 \mathrm{M} \mathrm{KOH} ; 70^{\circ} \mathrm{C}$ & 7.3 & [67] \\
\hline NiMo-modified Ni foam & 2.5 & $0.1 \mathrm{M} \mathrm{NaOH}, 25^{\circ} \mathrm{C}$ & $4.1 \times 10^{-2}$ & [28] \\
\hline $\mathrm{Ni}+$ Mo composite & 44 & $5 \mathrm{M} \mathrm{KOH} ; 25^{\circ} \mathrm{C}$ & 1.0 & [68] \\
\hline Ni-Mo-rGO & 30.8 & $1 \mathrm{M} \mathrm{KOH} ; 25^{\circ} \mathrm{C}$ & $4.31 \times 10^{-3}$ & [69] \\
\hline $\mathrm{Ni}-\mathrm{Mo}$ & 10.4 & \multirow{2}{*}{$7 \mathrm{M} \mathrm{KOH}, 25^{\circ} \mathrm{C}$} & $2.6 \times 10^{-2}$ & \multirow{2}{*}{ [62] } \\
\hline Co-Mo & 21.4 & & $2.3 \times 10^{-2}$ & \\
\hline \multirow{5}{*}{$\mathrm{Co}-\mathrm{Mo}$} & 40.9 & $1 \mathrm{M} \mathrm{NaOH}$ & 1.5 & [33] \\
\hline & 32 & $0.5 \mathrm{M} \mathrm{NaOH} ; 60^{\circ} \mathrm{C}$ & $6.9 \times 10^{-3}$ & [36] \\
\hline & 25 & $1 \mathrm{M} \mathrm{NaOH}, 25^{\circ} \mathrm{C}$ & 0.13 & [59] \\
\hline & 19 & $1 \mathrm{M} \mathrm{KOH}, 25^{\circ} \mathrm{C}$ & 0.36 & [70] \\
\hline & 33 & $1 \mathrm{M} \mathrm{NaOH}, 30^{\circ} \mathrm{C}$ & $5.0 \times 10^{-2}$ & [71] \\
\hline $\mathrm{Fe}-\mathrm{Mo}$ & 59.3 & $1 \mathrm{M} \mathrm{NaOH}, 25^{\circ} \mathrm{C}$ & $2.4 \times 10^{-3}$ & [39] \\
\hline
\end{tabular}

In order to obtain a more complete picture of electrocatalytic behavior for the HER, the corresponding $E_{\mathrm{a}}$ values for all tested systems have been calculated considering the linear dependence $\lg \left(i_{0}\right)=f(1 / T)$ using Arrhenius equation:

$$
E_{\mathrm{a}}=-2.303 R \frac{\partial\left(\lg i_{0}\right)}{\partial(1 / T)}
$$

where $E_{\mathrm{a}}$ is the activation energy $(\mathrm{J} / \mathrm{mol}), i_{0}$-apparent exchange current density, $T$-temperature $(\mathrm{K})$.

Figure 6 shows the Arrhenius plots for the as-deposited Ni-54 at.\% Mo, Co-52 at.\% Mo and $\mathrm{Fe}-54$ at.\% Mo electrodes. From the slope of these plots $E_{\mathrm{a}}$ values of $36.6,32.5$ and $27.9 \mathrm{~kJ} / \mathrm{mol}$ for $\mathrm{Fe}-\mathrm{Mo}, \mathrm{Ni}-\mathrm{Mo}$ and Co-Mo electrodes were determined, respectively. It is known that the lower the $E_{\mathrm{a}}$ value is, the lower the energy requirements for hydrogen production. Thus, it is obvious that the charge transfer rate is favored by Co-52 at.\% Mo alloys electrodeposition, since this electrode showed slightly lower activation energy than that of the Ni-54 at.\% Mo and Fe-54 at.\% Mo coatings.

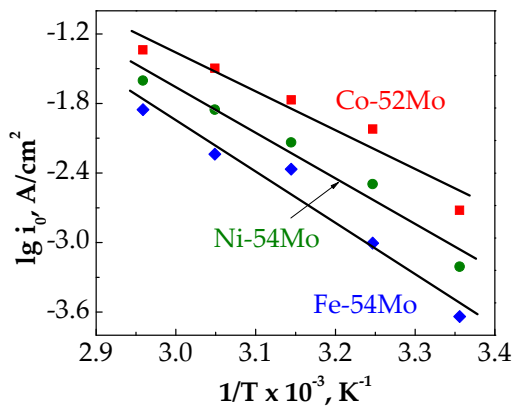

Figure 6. Arrhenius plots for $\mathrm{Ni}-54 \mathrm{Mo}, \mathrm{Co}-52 \mathrm{Mo}$ and Fe-54 Mo electrocatalysts (composition is given in at. $\%)$. 


\section{Conclusions}

- The electrodeposition of Mo-rich (36-82 at.\%) alloys with iron group metals (Ni, Co, Fe) from highly saturated ammonium acetate aqueous electrolytes is reported. The composition was affected by the $[\mathrm{Ni}(\mathrm{II})] /[\mathrm{Mo}(\mathrm{VI})]$ ratio in the plating bath and cathodic current density.

- The electro-catalytic activity towards cathodic hydrogen evolution in $30 \mathrm{wt} . \% \mathrm{NaOH}$ solution in the temperature range of $25-65{ }^{\circ} \mathrm{C}$ on the electrodeposited $\mathrm{Ni}-54$ at. $\% \mathrm{Mo}, \mathrm{Co}-52$ at. $\% \mathrm{Mo}$, $\mathrm{Fe}-54$ at.\% Mo and Co-52 at.\% Mo alloy coatings characterized by amorphous-like structure has been investigated.

- Bimetallic Mo-based alloys are considered as more active for the HER in comparison with the cast Mo and $\mathrm{Pt}$ since they demonstrate higher apparent exchange current densities in the tested temperature range. The apparent exchange current density of hydrogen for Co-52 at.\% Mo deposits were considerably higher than those for Ni-54 at.\% Mo and Fe-54 at.\% Mo alloy coatings and this can be attributed to the formation of stable intermetallic $\mathrm{Co}_{3} \mathrm{Mo}$ phase which ensures optimal Co and Mo distribution over the surface and produces larger active sites for the HER.

- The calculated activation energy values suggest that the Mo alloy coating with iron group metals shows promising electrocatalytic activity for the HER and among all investigated samples, the Co-52 at.\% Mo electrode is characterized by a lower activation energy $(27.9 \mathrm{~kJ} / \mathrm{mol})$ than the $\mathrm{Ni}-54$ at.\% $\mathrm{Mo}(32.5 \mathrm{~kJ} / \mathrm{mol})$ and $\mathrm{Fe}-54$ at.\% Mo (36.6 kJ/mol) coatings.

Author Contributions: Investigation, E.V. and O.B.; Methodology, E.V. and O.B.; Supervision, H.C. and N.T.; Visualization, E.V.; Writing-Original Draft Preparation, E.V.; Writing-Review \& Editing, E.V., H.C. and N.T.

Funding: This research has received funding from Horizon 2020 research and innovation program under MSCA-RISE-2017 (No. 778357) and from Research Lithuanian Council project (No 09.3.3-LMT-K-712-08-0003).

Conflicts of Interest: The authors declare no conflict of interest.

\section{References}

1. Studer, S.; Stucki, S.; Speight, J.D. Hydrogen as a Fuel. In Hydrogen as a Future Energy Carrier; Zttel, A., Borgschulte, A., Schlapbach, L., Eds.; Wiley-VCH Verlag GmbH \& Co. KGaA: Weinheim, Germany, 2008; pp. 23-69.

2. Sheng, W.; Gasteiger, H.A.; Shao-Horn, Y. Hydrogen oxidation and evolution reaction kinetics on platinum: Acid vs alkaline electrolytes. J. Electrochem. Soc. 2010, 157, B1529-B1536. [CrossRef]

3. Halim, J.; Abdel-Karim, R.; El-Raghy, S.; Nabil, M.; Waheed, A. Electrodeposition and characterization of nanocrystalline Ni-Mo catalysts for hydrogen production. J. Nanomater. 2012, 2012, 845673. [CrossRef]

4. Aaboubi, O. Hydrogen evolution activity of Ni-Mo coating electrodeposited under magnetic field control. Int. J. Hydrogen Energy 2011, 36, 4702-4709. [CrossRef]

5. Raj, I.A.; Venkatesan, V.K. Characterization of nickel-molybdenum and nickel-molybdenum-iron alloy coatings as cathodes for alkaline water electrolysers. Int. J. Hydrogen Energy 1988, 13, 215-223.

6. Kapoor, G.; Huang, Y.; Sarma, V.S.; Langdon, T.G.; Gubicza, J. Influence of Mo alloying on the thermal stability and hardness of ultrafine-grained Ni processed by high-pressure torsion. J. Mater. Res. Technol. 2017, 6, 361-368. [CrossRef]

7. Feng, C.; Qian, W.; Liu, J.; Han, S.; Fu, N.; Ye, F.; Lin, H.; Jiang, J. Effect of ultrasonication on Ni-Mo coatings produced by DC electroformation. RSC Adv. 2016, 6, 30652-30660. [CrossRef]

8. Laszczyńska, A.; Tylus, W.; Winiarski, J.; Szczygieł, I. Evolution of corrosion resistance and passive film properties of Ni-Mo alloy coatings during exposure to $0.5 \mathrm{M} \mathrm{NaCl}$ solution. Surf. Coat. Technol. 2017, 317, 26-37. [CrossRef]

9. Chassaing, E.; Portail, N.; Levy, A.-F.; Wang, G. Characterisation of electrodeposited nanocrystalline Ni-Mo alloys. J. Appl. Electrochem. 2004, 34, 1085-1091. [CrossRef]

10. Huang, P.-C.; Hou, K.-H.; Wang, G.-L.; Chen, M.-L.; Wang, J.-R. Corrosion resistance of the Ni-Mo alloy coatings related to coating's electroplating parameters. Int. J. Electrochem. Sci. 2015, 10, 4972-4984. 
11. Jakšić, J.M.; Vojnović, M.V.; Krstajić, N.V. Kinetic analysis of hydrogen evolution at Ni-Mo alloy electrodes. Electrochim. Acta 2000, 45, 4151-4158. [CrossRef]

12. Xu, C.; Zhou, J.; Zeng, M.; Fu, X.; Liu, X.; Li, J. Electrodeposition mechanism and characterization of $\mathrm{Ni}-\mathrm{Mo}$ alloy and its electrocatalytic performance for hydrogen evolution. Int. J. Hydrogen Energy 2016, 41, 13341-13349. [CrossRef]

13. Mech, K.; Zabinski, P.; Mucha, M.; Kowalik, R. Electrodeposition of catalytically active Ni-Mo alloys/elektroosadzanie aktywnych katalitycznie stopów Ni-Mo. Arch. Metall. Mater. 2013, 58, 227-229. [CrossRef]

14. Jeremiasse, A.W.; Bergsma, J.; Kleijn, J.M.; Saakes, M.; Buisman, C.J.N.; Cohen Stuart, M.; Hamelers, H.V.M. Performance of metal alloys as hydrogen evolution reaction catalysts in a microbial electrolysis cell. Int. J. Hydrogen Energy 2011, 36, 10482-10489. [CrossRef]

15. Navarro-Flores, E.; Chong, Z.; Omanovic, S. Characterization of Ni, NiMo, NiW and NiFe electroactive coatings as electrocatalysts for hydrogen evolution in an acidic medium. J. Mol. Catal. A Chem. 2005, 226, 179-197. [CrossRef]

16. Manazoğlu, M.; Hapçı, G.; Orhan, G. Electrochemical deposition and characterization of Ni-Mo alloys as cathode for alkaline water electrolysis. J. Mater. Eng. Perform. 2016, 25, 130-137. [CrossRef]

17. Martinez, S.; Metikoš-Huković, M.; Valek, L. Electrocatalytic properties of electrodeposited Ni-15Mo cathodes for the HER in acid solutions: Synergistic electronic effect. J. Mol. Catal. A Chem. 2006, 245, 114-121. [CrossRef]

18. Lu, G.; Evans, P.; Zangari, G. Electrocatalytic properties of Ni-based alloys toward hydrogen evolution reaction in acid media. J. Electrochem. Soc. 2003, 150, A551-A557. [CrossRef]

19. Huang, L.; Yang, F.; Xu, S.; Zhou, S. Studies of structure and electrocatalytic hydrogen evolution on electrodeposited nanocrystalline Ni-Mo alloy electrodes. Trans. IMF 2001, 79, 136-139. [CrossRef]

20. Kedzierzawski, P.; Oleszak, D.; Janik-Czachor, M. Hydrogen evolution on hot and cold consolidated Ni-Mo alloys produced by mechanical alloying. Mater. Sci. Eng. A 2001, 300, 105-112. [CrossRef]

21. González, G.; Sagarzazu, A.; Villalba, R.; Ochoa, J. Comparative study of NiW, NiMo and MoW prepared by mechanical alloying. J. Alloys Compd. 2007, 434-435, 525-529. [CrossRef]

22. Schulz, R.; Huot, J.Y.; Trudeau, M.L.; Dignard-Bailey, L.; Yan, Z.H.; Jin, S.; Lamarre, A.; Ghali, E.; Van Neste, A. Nanocrystalline Ni-Mo alloys and their application in electrocatalysis. J. Mater. Res. 1994, 9, 2998-3008. [CrossRef]

23. Yang, C.; Muránsky, O.; Zhu, H.; Thorogood, G.J.; Huang, H.; Zhou, X. On the origin of strengthening mechanisms in Ni-Mo alloys prepared via powder metallurgy. Mater. Des. 2017, 113, 223-231. [CrossRef]

24. Bhattacharjee, P.P.; Ray, R.K.; Upadhyaya, A. Development of cube texture in pure Ni, Ni-W and Ni-Mo alloys prepared by the powder metallurgy route. Scripta Materialia 2005, 53, 1477-1481. [CrossRef]

25. Tang, X.; Xiao, L.; Yang, C.; Lu, J.; Zhuang, L. Noble fabrication of Ni-Mo cathode for alkaline water electrolysis and alkaline polymer electrolyte water electrolysis. Int. J. Hydrogen Energy 2014, 39, 3055-3060. [CrossRef]

26. Li, X.; Liu, Z.; Wang, Y. Microstructure and corrosion properties of laser cladding MoNi based alloy coatings. Sci. China Technol. Sci. 2014, 57, 980-989. [CrossRef]

27. Aaboubi, O.; Chopart, J.-P. Magnetic field effect on molybdenum based alloys electrodeposition. ECS Trans. 2010, 25, 27-34.

28. Mikolajczyk, T.; Pierozynski, B. Influence of electrodeposited Ni-Mo alloy on hydrogen evolution reaction at nickel foam cathode. Int. J. Electrochem. Sc. 2018, 13, 621-630. [CrossRef]

29. González-Buch, C.; Herraiz-Cardona, I.; Ortega, E.M.; García-Antón, J.; Pérez-Herranz, V. Development of $\mathrm{Ni}-\mathrm{Mo}, \mathrm{Ni}-\mathrm{W}$ and Ni-Co macroporous materials for hydrogen evolution reaction. Chem. Eng. Trans. 2013, 32, 865-870.

30. Krstajic, N.V.; Jovic, V.D.; Gajic-krstajic, L.; Jovic, B.M.; Antozzi, A.L.; Martelli, G.N. Electrodeposition of $\mathrm{Ni}-\mathrm{Mo}$ alloy coatings and their characterization as cathodes for hydrogen evolution in sodium hydroxide solution. Int. J. Hydrogen Energy 2008, 33, 3676-3687. [CrossRef]

31. Donten, M.; Cesiulis, H.; Stojek, Z. Electrodeposition of amorphous/nanocrystalline and polycrystalline Ni-Mo alloys from pyrophosphate baths. Electrochim. Acta 2005, 50, 1405-1412. [CrossRef]

32. Gennero de Chialvo, M.R.; Chialvo, A.C. Hydrogen evolution reaction on smooth $\mathrm{Ni}(1-x)+\mathrm{Mo}(x)$ alloys $(0 \leq x \leq 0.25)$. J. Electroanal. Chem. 1998, 448, 87-93. [CrossRef] 
33. Kuznetsov, V.V.; Kalinkina, A.A.; Pshenichkina, T.V.; Balabaev, V.V. Electrocatalytic properties of cobalt-molybdenum alloy deposits in the hydrogen evolution reaction. Russ. J. Electrochem. 2008, 44, 1350-1358. [CrossRef]

34. Podlaha, E.J.; Landolt, D. Induced codeposition: 1. An experimental investigation of Ni-Mo alloys. J. Electrochem. Soc. 1996, 143, 885-892. [CrossRef]

35. Bigos, A.; Beltowska-Lehman, E.; Kot, M. Studies on electrochemical deposition and physicochemical properties of nanocrystalline Ni-Mo alloys. Surf. Coat. Technol. 2017, 317, 103-109. [CrossRef]

36. Casciano, P.N.S.; Benevides, R.L.; Santana, R.A.C.; Correia, A.N.; de Lima-Neto, P. Factorial design in the electrodeposition of Co-Mo coatings and their evaluations for hydrogen evolution reaction. J. Alloys Compd. 2017, 723, 164-171. [CrossRef]

37. Allahyarzadeh, M.H.; Roozbehani, B.; Ashrafi, A.; Shadizadeh, S.R.; Kheradmand, E. Electrochemically deposition of high Mo content amorphous/nanocrystalline Ni-Mo using ionic liquids as additive. ECS Trans. 2012, 41, 11-28.

38. Elezović, N.; Grgur, N.B.; Krstajić, N.V.; Jović, V.D. Electrodeposition and characterization of Fe-Mo alloys as cathodes for hydrogen evolution in the process of chlorate production. J. Serb. Chem. Soc. 2005, 70, 879-889.

39. Elezović, N.R.; Jović, V.D.; Krstajić, N.V. Kinetics of the hydrogen evolution reaction on Fe-Mo film deposited on mild steel support in alkaline solution. Electrochim. Acta 2005, 50, 5594-5601. [CrossRef]

40. Barbano, E.P.; de Carvalho, M.F.; Carlos, I.A. Electrodeposition and characterization of binary Fe-Mo alloys from trisodium nitrilotriacetate bath. J. Electroanal. Chem. 2016, 775, 146-156. [CrossRef]

41. Niedbała, J. Production of Ni - Mo + Mo composite coatings with increased content of embeded Mo. Arch. Mater. Sci. 2006, 27, 121-127.

42. Han, Q.; Cui, S.; Pu, N.; Chen, J.; Liu, K.; Wei, X. A study on pulse plating amorphous Ni-Mo alloy coating used as HER cathode in alkaline medium. Int. J. Hydrogen Energy 2010, 35, 5194-5201. [CrossRef]

43. Sun, S.; Podlaha, E.J. Electrodeposition of Mo-Rich, MoNi alloys from an aqueous electrolyte. J. Electrochem. Soc. 2012, 159, D97-D102. [CrossRef]

44. Morley, T.J.; Penner, L.; Schaffer, P.; Ruth, T.J.; Bénard, F.; Asselin, E. The deposition of smooth metallic molybdenum from aqueous electrolytes containing molybdate ions. Electrochem. Commun. 2012, 15, 78-80. [CrossRef]

45. Kahlert, H. Reference electrodes. In Electroanalytical Methods, 2nd ed.; Scholz, F., Ed.; Springer: Berlin/Heidelberg, Germany, 2010; pp. 291-308.

46. Fosdick, S.E.; Berglund, S.P.; Mullins, C.B.; Crooks, R.M. Evaluating electrocatalysts for the hydrogen evolution reaction using bipolar electrode arrays: $\mathrm{Bi}$ - and trimetallic combinations of $\mathrm{Co}, \mathrm{Fe}, \mathrm{Ni}, \mathrm{Mo}$, and $\mathrm{W}$. ACS Catal. 2014, 4, 1332-1339. [CrossRef]

47. Raj, I.A.; Vasu, K.I. Transition metal-based hydrogen electrodes in alkaline solution? electrocatalysis on nickel based binary alloy coatings. J. Appl. Electrochem. 1990, 20, 32-38. [CrossRef]

48. Sanches, L.S.; Domingues, S.H.; Marino, C.E.B.; Mascaro, L.H. Characterisation of electrochemically deposited Ni-Mo alloy coatings. Electrochem. Commun. 2004, 6, 543-548. [CrossRef]

49. Rodríguez-Valdez, L.; Estrada-Guel, I.; Almeraya-Calderon, F.; Neri-Flores, M.A.; Martinez-Villafane, A.; Martinez-Sanchez, R. Electrochemical performance of hydrogen evolution reaction of Ni-Mo electrodes obtained by mechanical alloying. Int. J. Hydrogen Energy 2004, 29, 1141-1145. [CrossRef]

50. Beltowska-Lehman, E. Kinetics of induced electrodeposition of alloys containing Mo from citrate solutions. Phys. Status Solidi C 2008, 5, 3514-3517. [CrossRef]

51. Benaicha, M.; Allam, M.; Dakhouche, A.; Hamla, M. Electrodeposition and characterization of W-rich NiW alloys from citrate electrolyte. Int. J. Electrochem. Sci. 2016, 11, 7605-7620. [CrossRef]

52. Bigos, A.; Bełtowska-Lehman, E.; Kania, B.; Szczerba, M. Ni-Mo alloys electrodeposited under direct current from citrate-ammonia plating bath. Inżynieria Materiałowa. 2013, 34, 135-139.

53. Costovici, S.; Manea, A.-C.; Visan, T.; Anicai, L. Investigation of Ni-Mo and Co-Mo alloys electrodeposition involving choline chloride based ionic liquids. Electrochim. Acta 2016, 207, 97-111. [CrossRef]

54. Karolus, M.; Łagiewka, E. Crystallite size and lattice strain in nanocrystalline Ni-Mo alloys studied by Rietveld refinement. J. Alloys Compd. 2004, 367, 235-238. [CrossRef]

55. Kuznetsov, V.V.; Golyanin, K.E.; Ladygina, Y.S.; Pshenichkina, T.V.; Lyakhov, B.F.; Pokholok, K.V. Electrodeposition of iron-molybdenum alloy from ammonium-citrate solutions and properties of produced materials. Russ. J. Electrochem. 2015, 51, 748-757. [CrossRef] 
56. Nicolenco, A.; Tsyntsaru, N.; Fornell, J.; Pellicer, E.; Reklaitis, J.; Baltrunas, D.; Cesiulis, H.; Sort, J. Mapping of magnetic and mechanical properties of Fe-W alloys electrodeposited from Fe(III)-based glycolate-citrate bath. Mater. Des. 2018, 139, 429-438. [CrossRef]

57. Kinh, V.Q.; Chassaing, E.; Saurat, M. Electroplating of crack-free corrosion resistant Co-Mo alloy coatings. Electrodepos. Surf. Treat. 1975, 3, 205-212. [CrossRef]

58. Jakšić, M.M. Advances in electrocatalysis for hydrogen evolution in the light of the Brewer-Engel valence-bond theory. J. Mol. Catal. 1986, 38, 161-202. [CrossRef]

59. Zhou, Q.F.; Lu, L.Y.; Yu, L.N.; Xu, X.G.; Jiang, Y. Multifunctional Co-Mo films fabricated by electrochemical deposition. Electrochim. Acta 2013, 106, 258-263. [CrossRef]

60. Lee, C.R.; Kang, S.G. Electrochemical stability of Co-Mo intermetallic compound electrodes for hydrogen oxidation reaction in hot $\mathrm{KOH}$ solution. J. Power Sources 2000, 87, 64-68. [CrossRef]

61. Conway, B.E.; Tessier, D.F.; Wilkinson, D.P. Temperature dependence of the Tafel slope and electrochemical barrier symmetry factor. J. Electrochem. Soc. 1989, 136, 2486-2493. [CrossRef]

62. Fan, C.; Piron, D.L.; Sleb, A.; Paradis, P. Study of electrodeposited nickel-molybdenum, nickel-tungsten, cobalt-molybdenum, and cobalt-tungsten as hydrogen electrodes in alkaline water electrolysis. J. Electrochem. Soc. 1994, 141, 382-387. [CrossRef]

63. Lupu, D.; Mărginean, P.; Biriş, A.R. Hydrogen in some synergetic electrocatalysts. J. Alloys Compd. 1996, 245, 146-152. [CrossRef]

64. Domínguez-Crespo, M.A.; Plata-Torres, M.; Torres-Huerta, A.M.; Arce-Estrada, E.M.; Hallen-López, J.M. Kinetic study of hydrogen evolution reaction on $\mathrm{Ni}_{30} \mathrm{Mo}_{70}, \mathrm{Co}_{30} \mathrm{Mo}_{70}, \mathrm{Co}_{30} \mathrm{Ni}_{70}$ and $\mathrm{Co}_{10} \mathrm{Ni}_{20} \mathrm{Mo}_{70}$ alloy electrodes. Mater. Charact. 2005, 55, 83-91. [CrossRef]

65. Manazoğlu, M.; Hapçı, G.; Orhan, G. Effect of electrolysis parameters of Ni-Mo alloy on the electrocatalytic activity for hydrogen evaluation and their stability in alkali medium. J. Appl. Electrochem. 2016, 46, 191-204. [CrossRef]

66. Shetty, S.; Mohamed Jaffer Sadiq, M.; Bhat, D.K.; Hegde, A.C. Electrodeposition and characterization of Ni-Mo alloy as an electrocatalyst for alkaline water electrolysis. J. Electroanal. Chem. 2017, 796, 57-65. [CrossRef]

67. Tasic, G.S.; Maslovara, S.P.; Zugic, D.L.; Maksic, A.D.; Marceta Kaninski, M.P. Characterization of the Ni-Mo catalyst formed in situ during hydrogen generation from alkaline water electrolysis. Int. J. Hydrogen Energy 2011, 36, 11588-11595. [CrossRef]

68. Panek, J.; Budniok, A. Ni + Mo composite coatings for hydrogen evolution reaction. Surf. Interface Anal. 2008, 40, 237-241. [CrossRef]

69. Shetty, S.; Sadiq, M.M.J.; Bhat, D.K.; Hegde, A.C. Electrodeposition of Ni-Mo-rGO composite electrodes for efficient hydrogen production in an alkaline medium. New J. Chem. 2018, 42, 4661-4669. [CrossRef]

70. Kublanovsky, V.S.; Yapontseva, Y.S. Electrocatalytic properties of Co-Mo alloys electrodeposited from a citrate-pyrophosphate electrolyte. Electrocatalysis 2014, 5, 372-378. [CrossRef]

71. Subramania, A.; Sathiyapriya, A.; Muralidharan, V. Electrocatalytic cobalt-molybdenum alloy deposits. Int. J. Hydrogen Energy 2007, 32, 2843-2847. [CrossRef]

(C) 2019 by the authors. Licensee MDPI, Basel, Switzerland. This article is an open access article distributed under the terms and conditions of the Creative Commons Attribution (CC BY) license (http:/ / creativecommons.org/licenses/by/4.0/). 